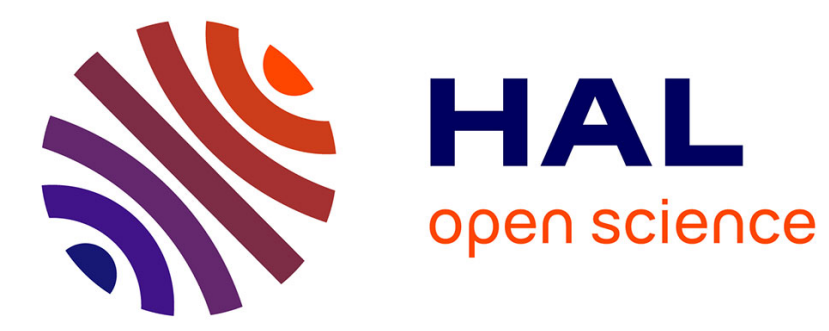

\title{
Synthesis and properties of photoswitchable diphosphines and gold(I) complexes derived from azobenzenes
}

Clément Cazorla, Lorenzo Casimiro, Tanzeel Arif, Claire Deo, Nawel Goual, Pascal Retailleau, Rémi Métivier, Juan Xie, Arnaud Voituriez, Angela

Marinetti, et al.

\section{To cite this version:}

Clément Cazorla, Lorenzo Casimiro, Tanzeel Arif, Claire Deo, Nawel Goual, et al.. Synthesis and properties of photoswitchable diphosphines and gold(I) complexes derived from azobenzenes. Dalton Transactions, 2021, 50 (21), pp.7284-7292. 10.1039/d1dt01080h . hal-03298302

\section{HAL Id: hal-03298302 \\ https://hal.science/hal-03298302}

Submitted on 23 Jul 2021

HAL is a multi-disciplinary open access archive for the deposit and dissemination of scientific research documents, whether they are published or not. The documents may come from teaching and research institutions in France or abroad, or from public or private research centers.
L'archive ouverte pluridisciplinaire HAL, est destinée au dépôt et à la diffusion de documents scientifiques de niveau recherche, publiés ou non, émanant des établissements d'enseignement et de recherche français ou étrangers, des laboratoires publics ou privés. 


\title{
Synthesis and properties of photoswitchable diphosphines and gold(I) complexes derived from azobenzenes
}

\author{
Clément Cazorla, ${ }^{\mathrm{a}, \mathrm{b}}$ Lorenzo Casimiro, ${ }^{\mathrm{b}}$ Tanzeel Arif,, ${ }^{\mathrm{a}, \mathrm{b}}$ Claire Deo, ${ }^{\mathrm{b}}$ Nawel Goual, ${ }^{\mathrm{a}}$ Pascal Retailleau, ${ }^{\mathrm{a}}$ \\ Rémi Métivier, ${ }^{b}$ Juan Xie, ${ }^{* b}$ Arnaud Voituriez, ${ }^{* a}$ Angela Marinetti*a and Nicolas Bogliotti*b

\begin{abstract}
Diphosphines displaying azobenzene scaffolds and the corresponding bis-gold chloride complexes have been prepared and fully characterized by photophysical, spectroscopic and X-ray diffraction studies. DFT calculations provide complementary information on their electronic, structural and spectroscopic properties. Comparative investigations have been carried out on compounds featuring phosphorus functions in the meta- and para-positions, respectively, with respect to the azo functions, as well as on diphosphines with an ortho-tetrafluoro substituted azobenzene core. The effects of the substitution patterns on structural and spectroscopic properties are discussed.
\end{abstract}

\section{Introduction}

The chemistry of photochromic compounds including metal complexes has been the subject of strong interest over the last decade, with the aim of creating "smart" systems, able to perform a specific function or to tune their behaviour in response to light. Molecular photoswitches thus received attention as powerful tools for the external control of biological systems, ${ }^{1,2}$ molecular electronic devices, ${ }^{3}$ artificial molecular machines, ${ }^{4-7}$ functional materials ${ }^{8}$ and energy storage devices, ${ }^{9}$ among others. ${ }^{10-13}$ Notably, photoswitchable ligands and organocatalysts have been designed for the remote control of the catalytic activity by means of non-invasive stimuli. ${ }^{14-17}$

Photoresponsive trivalent phosphines and their metal complexes have been only scarcely considered in this context. [For phosphines with photoresponsive dithienylethene or stiffstilbene scaffolds, see: ${ }^{18-23}$ ] Notably, concerning azobenzenederived phosphines, synthetic approaches and some photophysical characterizations have been disclosed, but only sparse examples of systematic photophysical studies and uses have been reported. [Selected references on azobenzenederived phosphines: ${ }^{24-32}$ ] Thus, having noticed that the area of photoswitchable phosphines might be somewhat underdeveloped, ${ }^{33}$ in regard to their huge application potential in coordination chemistry and catalysis, we have initiated recently investigations in this field.

In our previous paper, we have reported on a diphosphine featuring a tetrafluoroazobenzene core, $\mathbf{1}^{\prime}$, as well as on its bimetallic gold(I) complex 1 (Fig. 1). ${ }^{34}$ The catalytic activity of this complex in hydroamination reactions was found to be significantly affected by the $E / Z$ isomerization of the photoswitching unit. This effect has been ascribed to an enhanced cooperativity between the two gold centers in the $Z$ form of the catalyst.

As a complement to these previous studies, we report herein the synthesis of novel azobenzene-based diphosphines and the corresponding gold(I) complexes, their structural analyses (Xray diffraction) and detailed description of their photophysical and photochemical properties, substantiated by theoretical studies (DFT and TD-DFT). Moreover, theoretical investigations on phosphine 1' and the gold complex $\mathbf{1}$ are also reported for comparative purpose.

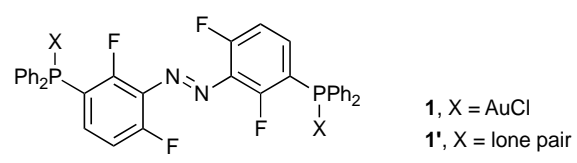

Fig. 1 Bis(diphenylphosphino)-azobenzene 1' and the bimetallic gold complex 1, from previous studies. ${ }^{34}$

\section{Results and discussion}

\section{Synthesis and photoisomerization studies.}

Previous studies in the field of azobenzene-phosphines mainly relate to monophosphorus derivatives, while, surprisingly, the chemistry of the analogous diphosphines is largely unexplored. ${ }^{34,} 35$ Moreover, despite the increasing interest towards gold coordination chemistry and catalysis, ${ }^{36-39}$ only a handful of gold(I) complexes bearing either azobenzene-derived phosphines $^{40}$ or other photoswitchable phosphorus ligands have been described to date. ${ }^{18,41,42}$ In this context, we have initiated systematic investigations on azobenzene-diphosphines and their gold complexes, typified hereafter by the parent meta- and para-bis(diphenylphosphino)azobenzenes $\mathbf{3}$ and $\mathbf{6}$.

These phosphines and their $\mathrm{Au}(\mathrm{I})$-complexes $\mathbf{4}$ and $\mathbf{7}$ have been synthesized as shown in Scheme 1. In both cases, the key step is the palladium promoted phosphination of a suitable, preformed diiodoazobenzene. ${ }^{26}$

Thus, the meta- and para-diiodo-azobenzenes $2^{43}$ and $\mathbf{5}^{44}$ were reacted with $\mathrm{Ph}_{2} \mathrm{PH}$ in the presence of a catalytic amount of $\mathrm{Pd}\left(\mathrm{PPh}_{3}\right)_{4}$ and triethylamine, in toluene at $100^{\circ} \mathrm{C}$. The desired azobenzene-derived diphosphines $E-3$ and $E-6$ were obtained in $66 \%$ and $69 \%$ yields, respectively. The gold(I)-chloride complexes E-4 and E-7 were obtained then in 93\% and $90 \%$ yields respectively by adding ligands $\mathbf{3}$ or $\mathbf{6}$ to an $\mathrm{Au}(\mathrm{I})$ solution generated by reduction of the gold(III) precursor $\mathrm{NaAuCl}_{4}$ with $2,2^{\prime}$-thiodiethanol.

Both the phosphines and the gold complexes were fully characterized and their photochemical isomerization was investigated then by spectroscopic methods (Table 1 ). 

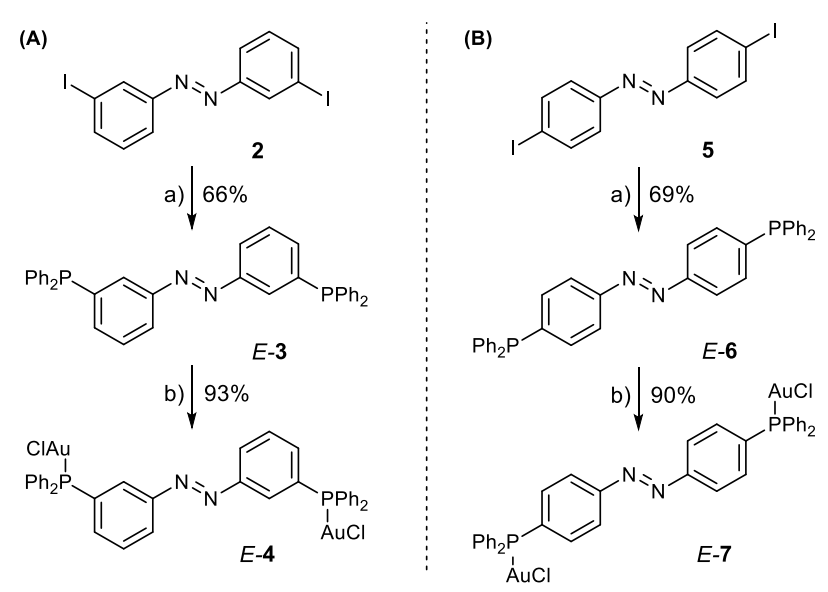

Reaction conditions:

a) $\mathrm{Ph}_{2} \mathrm{PH}, \mathrm{Et}_{3} \mathrm{~N}$, cat. $\mathrm{Pd}\left(\mathrm{PPh}_{3}\right)_{4}$, toluene, $100^{\circ} \mathrm{C}, 16 \mathrm{~h}$.

b) $\mathrm{NaAuCl}_{4}\left(\mathrm{H}_{2} \mathrm{O}\right)_{2}, 2,2^{\prime}$-thiodiethanol, $\mathrm{H}_{2} \mathrm{O}$, then $\mathbf{3}$ or $\mathbf{6}, \mathrm{CHCl}_{3}, 0^{\circ} \mathrm{C}$

Scheme 1 Synthesis of the 3,3'- and 4,4'-bis(diphenylphosphino)azobenzenes $E$-3 and $E-6$, and their gold complexes E-4 and E-7.

Table $1{ }^{31}$ P NMR chemical shifts and UV-vis absorption max for the azobenzenephosphines and gold(I) complexes. Calculated max for pure $Z$ compounds

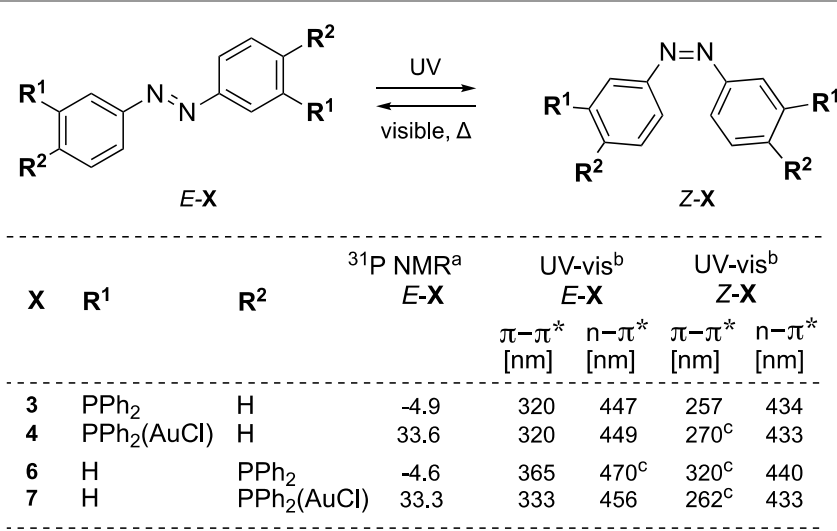

${ }^{a}$ chemical shift in $\mathrm{CDCl}_{3} ;{ }^{b} \lambda_{\max }$ in $\mathrm{MeCN} ;{ }^{c}$ shoulder

The photophysical and photochemical characterization of all the compounds was carried out in MeCN. However, the scarce solubility in this solvent did not allowed a reliable absorption coefficient determination. The absorption spectrum of the meta-bis(diphenylphosphino)-azobenzene $E$-3 (Fig. 2) shows an intense absorption band at $320 \mathrm{~nm}$, corresponding to the $\pi-\pi^{*}$ electronic transition, and a weaker band at $447 \mathrm{~nm}$, corresponding to the forbidden $n-\pi^{*}$ transition. The energy of these absorption maxima is in line with those of the unsubstituted azobenzene. ${ }^{45}$ In the gold complex E-4, the position of the two bands is substantially unchanged $\left(\lambda_{\max }=320\right.$ $\mathrm{nm}$ and $449 \mathrm{~nm})$, although the structure of the $\pi-\pi^{*}$ band becomes more pronounced. Contrariwise, if the phosphines are placed in para-position, the electronic effect exerted on the absorption spectrum is stronger. For the para- ligand $E-6$, the $\pi$ $\pi^{*}$ band is centered at $365 \mathrm{~nm}$ - redshifted of $45 \mathrm{~nm}$ with respect to $E-3$ - and partially overlapped to the $n-\pi^{*}$ band. In the corresponding gold complex $E-7$, the redshift is less intense and the $\pi-\pi^{*}$ and $n-\pi^{*}$ bands are better resolved, being observed at $333 \mathrm{~nm}$ and $456 \mathrm{~nm}$, respectively.

The optical features of $E-6$ would suggest that, when the functionalization is in para-position, the electron-donating phosphorus atoms are involved in the conjugation, as it happens for amino-azobenzene. ${ }^{45}$ This effect is less intense in $E$ 7, where the lone pair is involved in the complexation of the metal. Conversely, when the functionalization is in metaposition, the phosphorus atoms are less involved in the conjugation and the resulting spectrum is comparable with azobenzene-type compounds and insensitive to the complexation.

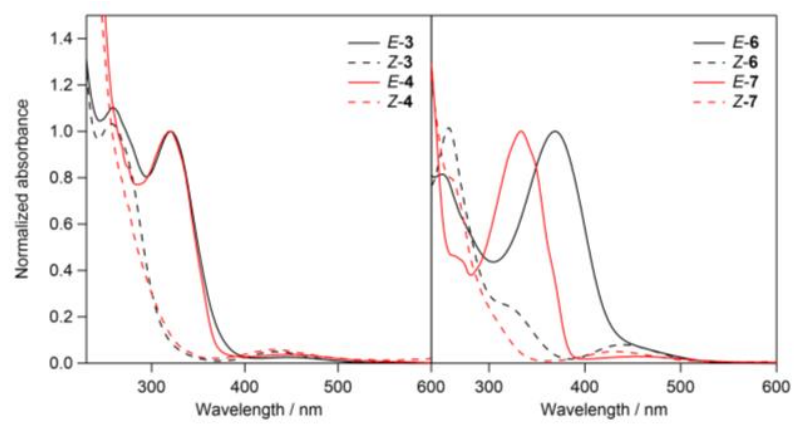

Fig. 2 Left: absorption spectrum in MeCN of the $E$ - (full lines) and $Z$ - (dashed lines, extrapolated spectra) isomers of $\mathbf{3}$ (black, left) and $\mathbf{4}$ (red, left) and of $\mathbf{6}$ (black, right) and $\mathbf{7}$ (red, right).

Upon UV irradiation ( $313 \mathrm{~nm}, 334 \mathrm{~nm}$ or $365 \mathrm{~nm}$ ), under inert atmosphere, all the compounds displayed absorbance variations consistent to a $E$-to- $Z$ photoisomerization (Fig. 3): the $\pi-\pi^{*}$ band decreased, while the $n-\pi^{*}$ increased, until a photostationary state (PSS) was achieved. In the case of the gold complexes, the $n-\pi^{*}$ band was also blueshifted of few nanometres with respect to the $E$ isomer. In the same way, visible irradiation $(436 \mathrm{~nm}$ ) on solutions previously irradiated in the UV promoted Z-to-E photoisomerization (Fig. SI1).

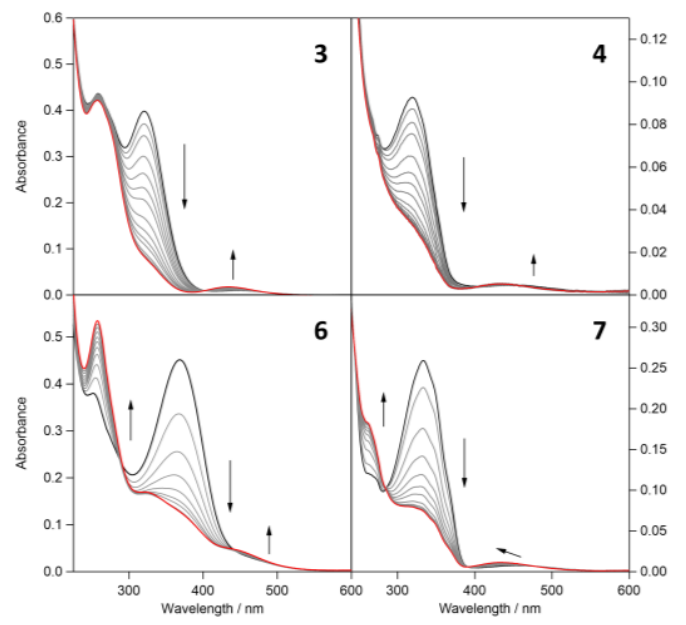

Fig. 3 Absorption evolutions in MeCN upon irradiation at $365 \mathrm{~nm}$ of $\mathbf{3}$ (top left), 4 (top right), 6 (bottom left), 7 (bottom right). 
By applying the Fischer method 46 to the spectra of photostationary states obtained upon irradiation at different wavelengths (Fig. SI2), we were able to extract the spectrum of the pure $Z$ form (Fig. 2) and to calculate consequently the $E / Z$ ratio at each PSS. Generally, if UV light is employed, all the $E$ compounds reach good photoconversion rates, with up to $87 \%$ conversion observed for E-3 under irradiation at $334 \mathrm{~nm}$ (Table 2). If visible light is employed, the PSSs are more shifted toward the $E$ form. Interestingly, upon irradiation of an $E / Z-7$ mixture at $436 \mathrm{~nm}$, an $E: Z$ ratio of 96:4 was reached, meaning that visible light can trigger an almost complete reset to the $E$ form of the gold complex 7 (Table 2).

Through fatigue resistance experiments, we proved that the photoswitching between two different PSSs is completely reversible and can be repeated up to 10 cycles without any evidence of photodegradation (Fig. SI3).

We investigated the thermal isomerization kinetics at $60^{\circ} \mathrm{C}$ after exhaustive irradiation of the $E$-forms of 3, 4, 6 and 7 at $365 \mathrm{~nm}$ (see Fig. 4, SI4 and Table 3). In line with the optical features, the resulting kinetic constants confirmed that for the metaderivatives, where the electron-donating effect of the phosphorus atom is less prominent, the thermal isomerization is slower, with rate constants in the order of $10^{-5} \mathrm{~s}^{-1}$, corresponding to half-lives $t_{1 / 2}$ ranging from 268 to 326 minutes. For the para-derivatives, the thermal isomerization is about 10fold faster, in the order of $10^{-4} \mathrm{~s}^{-1}\left(t_{1 / 2}=54-98\right.$ minutes). ${ }^{47,48}$

Table 2. UV-vis photoconversions of azobenzene-phosphines and gold complexes.

\begin{tabular}{|c|c|c|c|c|}
\hline & $\begin{array}{c}E: Z \\
313 \mathrm{~nm}^{\mathrm{a}}\end{array}$ & $\begin{array}{c}\mathrm{E}: Z \\
334 \mathrm{~nm}^{\mathrm{a}}\end{array}$ & $\begin{array}{c}\mathrm{E}: Z \\
365 \mathrm{~nm}^{\mathrm{a}}\end{array}$ & $\begin{array}{c}\mathrm{E}: Z \\
436 \mathrm{~nm}^{\mathrm{a}}\end{array}$ \\
\hline $\mathbf{3}$ & $35: 65$ & $13: 87$ & $13: 87$ & $81: 19$ \\
\hline $\mathbf{4}$ & $44: 56$ & $18: 82$ & $30: 70$ & $83: 17$ \\
\hline $\mathbf{6}$ & $75: 25$ & $60: 40$ & $18: 82$ & $72: 28$ \\
\hline $\mathbf{7}$ & $74: 26$ & $60: 40$ & $25: 75$ & $96: 4$ \\
\hline
\end{tabular}

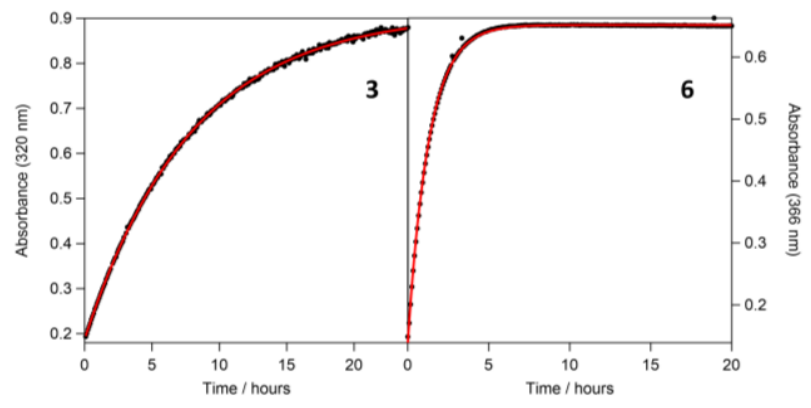

Fig. 4 Absorbance evolution in the dark at $60^{\circ} \mathrm{C}$ in MeCN (black dots) for 3 (left, $320 \mathrm{~nm}$ ) and 6 (right, $366 \mathrm{~nm}$ ), and fitting (red line), after exhaustive irradiation at $365 \mathrm{~nm}$.
The half-lives of the trivalent phosphine $Z-3$ and its gold(I) complex Z-4 are of more than 50-fold lower than those of the corresponding $o$-difluorinated phosphine $\mathbf{1}^{\prime}$ and gold complex $\mathbf{1}$ (Fig. 1), that were measured at $219 \mathrm{~h}$ and $278 \mathrm{~h}$ respectively. ${ }^{34}$ This effect is fully consistent with literature data that have demonstrated the increased thermal stability of $o$-fluorinesubstituted $Z$-azobenzenes. ${ }^{49-52}$ The effect has been ascribed, in polar solvents, to the increased dipole moment of the $Z$ isomers, induced by the fluoride substituents. ${ }^{53}$

Table 3. Thermal isomerization parameters of azobenzene-phosphines and gold complexes.

\begin{tabular}{|c|c|c|}
\hline & $\mathrm{k}^{\mathrm{a}}$ & $t_{1 / 2}{ }^{\mathrm{b}}$ \\
\hline $\mathbf{3}$ & $3.54 \times 10^{-5} \mathrm{~s}^{-1}$ & $326 \mathrm{~min}$ \\
\hline $\mathbf{4}$ & $4.31 \times 10^{-5} \mathrm{~s}^{-1}$ & $268 \mathrm{~min}$ \\
\hline $\mathbf{6}$ & $2.15 \times 10^{-4} \mathrm{~s}^{-1}$ & $54 \mathrm{~min}$ \\
\hline $\mathbf{7}$ & $1.18 \times 10^{-4} \mathrm{~s}^{-1}$ & $98 \mathrm{~min}$ \\
\hline $\mathbf{1}$ & --- & $219 \mathrm{~h}^{\mathrm{c}}$ \\
\hline $\mathbf{1}$ & --- & $278 \mathrm{~h}^{\mathrm{c}}$ \\
\hline
\end{tabular}

a Kinetic constant for the thermal isomerization at $60{ }^{\circ} \mathrm{C}$ in $\mathrm{MeCN}$; ${ }^{b}$ Half-life at 60 ${ }^{\circ} \mathrm{C}$ in $\mathrm{MeCN}$; c from ref. ${ }^{34}$

\section{X-ray diffraction and DFT studies.}

Single crystals of the bimetallic gold(I) complexes E-4 and E-7, suitable for $\mathrm{X}$-ray diffraction studies, were obtained by slow evaporation of a chloroform solution. ORTEP drawings for the two complexes are displayed in Fig. 5. Selected bond lengths and angles are given in Table 4. For comparison, X-ray data for the fluorinated azobenzene phosphine complexes $E / Z-1$ are also given. ${ }^{34}$

Both diphosphine complexes $\mathbf{4}$ and $\mathbf{7}$ adopt extended conformations, with the gold centers on opposite faces of the plane defined by the azobenzene core. Both complexes exhibit planar arrangements of the azo unit, as revealed by the $180.0^{\circ}$ values of the dihedral angle $\Psi(\mathrm{C}(8)-\mathrm{N}(10)-\mathrm{N}(11)-\mathrm{C}(12)$ angles). Bond distances are similar for the two compounds: $\mathrm{Au}-\mathrm{Cl}, 2.277$ and $2.279 \AA$, Au-P, 2.230 and $2.227 \AA$; N-C, 1.423 and $1.418 \AA$ for $E-4$ and $E-7$ respectively. In the $m$-substituted complex $E-4$ the $\mathrm{N}-\mathrm{N}$, bond (1.255 $\AA$ ) is slightly longer than in $E-7$ (1.238 $\AA$ ). For comparison, the $\mathrm{N}-\mathrm{N}$ bond length of the non-substituted trans-azobenzene measures $1.249 \AA .54$

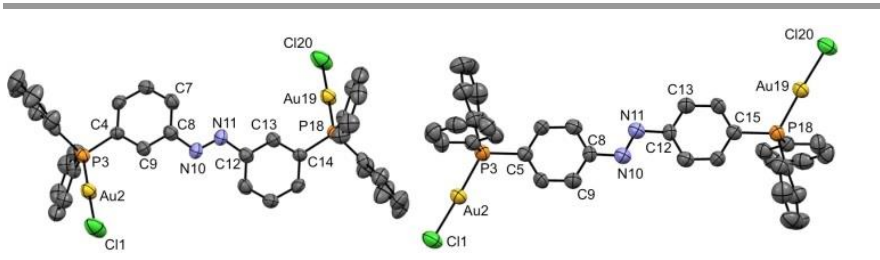

Fig. 5 ORTEP drawings for complexes $E-4$ (left) and E-7 (right), thermal ellipsoids drawn at the $30 \%$ probability level. 
Table 4. Selected bond lengths $(\AA)$ and angles (deg) for the gold complexes E-4, E-7, E-1 and Z-1, from X-ray crystal structures.

\begin{tabular}{|c|c|c|c|c|}
\hline & $E-\mathbf{4}$ & $E-\mathbf{7}$ & $E-\mathbf{1}^{34}$ & $Z-\mathbf{1}^{34}$ \\
\hline $\mathrm{Cl}(1)-\mathrm{Au}(2)$ & $2.277(2)$ & $2.279(2)$ & $2.276(8)$ & $2.280(2)$ \\
\hline $\mathrm{Cl}(20)-\mathrm{Au}(19)$ & $2.277(2)$ & $2.279(2)$ & $2.276(8)$ & $2.269(2)$ \\
\hline $\mathrm{Au}(2)-\mathrm{P}(3)$ & $2.230(2)$ & $2.227(2)$ & $2.226(7)$ & $2.228(1)$ \\
\hline $\mathrm{Au}(19)-\mathrm{P}(18)$ & $2.230(2)$ & $2.227(2)$ & $2.226(7)$ & $2.223(1)$ \\
\hline $\mathrm{P}(3)-\mathrm{C}(4)$ & $1.815(7)$ & & $1.82(2)$ & $1.824(6)$ \\
\hline $\mathrm{P}(18)-\mathrm{C}(14)$ & $1.815(7)$ & - & $1.82(2)$ & $1.824(6)$ \\
\hline $\mathrm{P}(3)-\mathrm{C}(5)$ & & $1.832(5)$ & & \\
\hline $\mathrm{P}(18)-\mathrm{C}(15)$ & - & $1.832(5)$ & - & \\
\hline $\mathrm{N}(10)-\mathrm{C}(8)$ & $1.423(9)$ & $1.418(7)$ & $1.47(3)$ & $1.447(7)$ \\
\hline $\mathrm{N}(11)-\mathrm{C}(12)$ & $1.423(9)$ & $1.418(7)$ & $1.47(3)$ & $1.436(7)$ \\
\hline $\mathrm{N}(10)-\mathrm{N}(11]$ & $1.255(9)$ & $1.238(6)$ & $1.26(3)$ & $1.238(8)$ \\
\hline$\Psi \mathrm{C}(8)-\mathrm{N}(10)-$ & $180.0(6)$ & $180.0(4)$ & $180(2)$ & $2.9(8)$ \\
$\mathrm{N}(11)-\mathrm{C}(12)^{\mathrm{b}}$ & & & & \\
\hline $\mathrm{C}(9)-\mathrm{C}(8)-$ & 180.0 & 180.0 & 180 & 29.5 \\
$\mathrm{C}(12)-\mathrm{C}(13)$ & & & & \\
\hline$\Phi \mathrm{C}(7)-\mathrm{C}(8)-$ & 14.1 & $4.6(8)$ & $42(3)^{\mathrm{c}}$ & $60.8(8)$ \\
\hline $\mathrm{N}(10)-\mathrm{N}(11)$ & & & & \\
\hline
\end{tabular}

a Values from one of the two independent molecules present in the unit cell. ${ }^{\mathrm{b}}$ Absolute value. ${ }^{\mathrm{c}} \Phi \mathrm{C}(9)-\mathrm{C}(8)-\mathrm{N}(10)-\mathrm{N}(11)$.

Atom numbering for compounds in the Table:
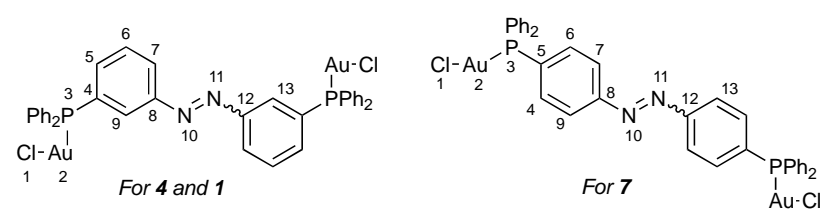

The $\boldsymbol{o}$-fluorine substituents in $\mathbf{1}$ do not affect substantially bond parameters. However, it appears clearly that they induce a rotation of the aryl rings out of the $\mathrm{C}-\mathrm{N}=\mathrm{N}-\mathrm{C}$ plane (Fig. 6 ). In the solid state, the dihedral angle $\Phi$ between the phenyl rings and the azobenzene plane increases indeed from $14.1^{\circ}$ to $42^{\circ}$ moving from non-fluorinated $E-4$ to the fluorinated analogue $E$ 1. Rotation of the aryl rings out of the plane of the diazo bond had been reported notably for the parent tetra-ofluoroazobenzene. ${ }^{55}$ Its optimized geometry from DFT calculations showed a dihedral angle $\Phi=27.7^{\circ}$, which is broadly consistent with the experimental value observed for $E$ 1.

The $p$-diphenylphosphino-substituted compound E-7 displays an almost planar arrangement, with a dihedral angle $\Phi=4.6^{\circ}$.
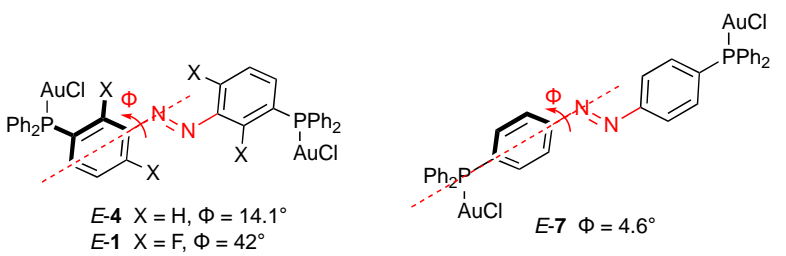
$E-1 \quad X=F, \Phi=42^{\circ}$
Fig. 6 Structural features of complexes E-4 and E-1 and E-7: dihedral angles $\Phi$ between the $\mathrm{C}-\mathrm{N}=\mathrm{N}-\mathrm{C}$ plane and the aryl planes.

These structural data are indicative of the preference of nonsubstituted azobenzenes and $o$-substituted azobenzenes for planar and non-planar arrangements, respectively. However, the absolute $\Phi$ values should be taken with caution since azobenzenes display conformational flexibility in solution and a high degree of variation of dihedral angles in the solid state. ${ }^{54,}$ 55

To get insights into the electronic features of the $E / Z$ diphosphines and gold complexes 3, 4, 6, 7, 1' and 1, geometry optimization were performed at the B3LYP level using the 6311G(d,p) (for 3, 4, 6 and 7) and the 6-311++G (for 1 and 1') basis sets (LANL2DZ for Au atom), taking into account the effect of solvent (MeCN) with C-PCM model. ${ }^{56}$ Views of the optimized geometries of Z-4 and Z-7 are given in Fig. 7 as representative examples. Other data are reported in the SI section. For Z-4 and Z-7, the calculated bond distances and angles do not show significant changes with respect to the corresponding $E$ isomers, except for dihedral angle values. Notably, as expected, in the Z-forms the two aryl rings are twisted out of the azobenzene plane so as to minimize the mutual steric hindrance ( $\Phi=53.3$ and $53.4^{\circ}$ for $Z-4$ and $Z-7$ respectively). Other relevant dihedral angle values are: $\Psi \mathrm{C}(8)-\mathrm{N}(10)-\mathrm{N}(11)-\mathrm{C}(12)=8.5$ and 9.2, for $Z-4$ and $Z-7$ respectively, and $C(9)-C(8)-C(12)-C(13)=$ 95.2 and 95.8 (for $Z-4$ and $Z-7$ ).

The almost invariant main bond parameters emphasize the ability of azobenzene-derived diphosphine ligands to photocontrol the relative orientation of the two metal centers in their complexes, without affecting the other main bond parameters.

The electronic transitions relevant to both $E$ - and Z-ligands 3 and 6 and the $A u(I)$ complexes 4 and $\mathbf{7}$ were calculated by TDDFT at the CAM-B3LYP level using the $6-311+G(d, p)$ basis set (LANL2DZ for $\mathrm{Au}$ ) and C-PCM model for MeCN. ${ }^{56}$
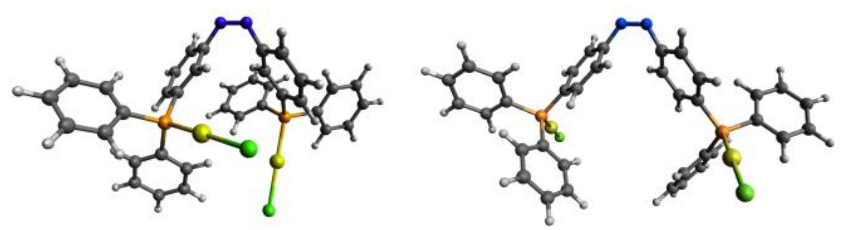

Fig. 7 DFT-optimized structures of complexes $Z-4$ and $Z-7$ at the C-PCMB3LYP/6-311G(d,p)[H,C,N,P,Cl]/LANL2DZ[Au] level in MeCN.

The involvement of multiple orbitals precluded straightforward visualization of electronic excitation, thereby leading us to generate natural transition orbitals (NTOs) for a qualitative description. ${ }^{57}$

The calculated characteristic UV and visible bands of the $E$ and $Z$ isomers showed good agreement with the experimental values (Table 5). Indeed, for ligand $E-3$ and the $\mathrm{Au}(\mathrm{I})$ complexes $E-4$ and $E-7$, calculations predict absorption bands between 315 and $339 \mathrm{~nm}$, in keeping with the experimental spectra 
measured in MeCN (320-333 nm). These transitions involve orbitals localized on the azobenzene core and exhibit a dominant $\pi \rightarrow \pi^{*}$ character (Fig. 8a and SI11).

Interestingly, the redshift to $365 \mathrm{~nm}$ observed in the case of $E$ 6 (bearing a diphenylphosphino-substituent in para position to the $\mathrm{N}=\mathrm{N}$ bond), is accurately predicted by calculations ( $363 \mathrm{~nm}$ ). It is found to originate from the extended overlap of the azobenzene $\pi$ system with orbitals of the P atom (Fig. 8b).

Table 5. Characteristic absorption wavelengths for the $E / Z$ isomers of the diphosphines and gold complexes

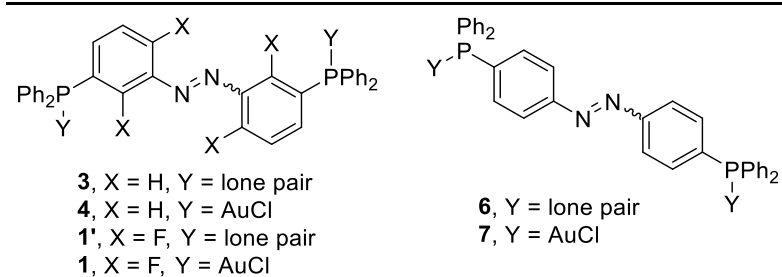

\begin{tabular}{|c|c|c|c|c|}
\hline & \multicolumn{2}{|c|}{$\mathrm{S}_{0} \rightarrow \mathrm{S}_{2}[\mathrm{~nm}]$} & \multicolumn{2}{|c|}{$\mathrm{S}_{0} \rightarrow \mathrm{S}_{1}[\mathrm{~nm}]$} \\
\hline & exp. $^{a}$ & calc. ${ }^{b}$ & exp. ${ }^{a}$ & calc. ${ }^{b}$ \\
\hline$E-3$ & 320 & $330^{\mathrm{c}}$ & 447 & $454^{\mathrm{d}, \mathrm{e}}$ \\
\hline Z-3 & 257 & 286 & 434 & $456^{\mathrm{d}}$ \\
\hline$E-4$ & 320 & $315^{\mathrm{c}}$ & 449 & $457^{\mathrm{d}, \mathrm{e}}$ \\
\hline Z-4 & $270^{f}$ & 274 & 433 & $451^{\mathrm{d}}$ \\
\hline$E-6$ & 365 & $363^{c}$ & $470^{\mathrm{f}}$ & $458^{\mathrm{d}}$ \\
\hline Z-6 & $320^{f}$ & 302 & 440 & $465^{\mathrm{d}}$ \\
\hline$E-7$ & 333 & $339^{c}$ & 456 & $469^{\mathrm{d}, \mathrm{e}}$ \\
\hline Z-7 & $262^{f}$ & 282 & 433 & $459^{d}$ \\
\hline$E-1$ ' & 304 & $335^{\mathrm{c}}$ & 455 & $508^{\mathrm{d}, \mathrm{e}}$ \\
\hline$Z-1$ & nd & 304 & 418 & $441^{d}$ \\
\hline$E-1$ & $310^{g}$ & $325^{c}$ & $456^{\mathrm{g}}$ & $509^{d}$ \\
\hline Z-1 & $293^{f, g}$ & 283 & $422^{\mathrm{g}}$ & $441^{\mathrm{d}}$ \\
\hline
\end{tabular}

a Experimental values in MeCN solution. ${ }^{b}$ calculated values in $\mathrm{MeCN}$ using the $\mathrm{C}$ PCM-TD-CAM-B3LYP/6-311+G(d,p) [H,C,N,P,Cl]/LANL2DZ[Au]//C-PCM-B3LYP/6 $311 \mathrm{G}(\mathrm{d}, \mathrm{p})[\mathrm{H}, \mathrm{C}, \mathrm{N}, \mathrm{P}, \mathrm{Cl}] / \mathrm{LANL2DZ}[\mathrm{Au}]$ method for $E / Z-3 / 4 / 6 / 7$, the C-PCM-TD-CAMB3LYP/6-311+G(d,p) [H,C,N,F,P,Cl]/LANL2DZ[Au]//C-PCM-

B3LYP/6311++G[H,C,N,F,P,Cl]/LANL2DZ[Au] method for E/Z-1/1'. ' Shows dominant $\pi \rightarrow \pi^{*}$ character. d Shows dominant $n \rightarrow \pi^{*}$ character. e Shows oscillato strength close to $0 .{ }^{f}$ Shoulder. ${ }^{g}$ From ref ${ }^{34}$. nd: not determined.

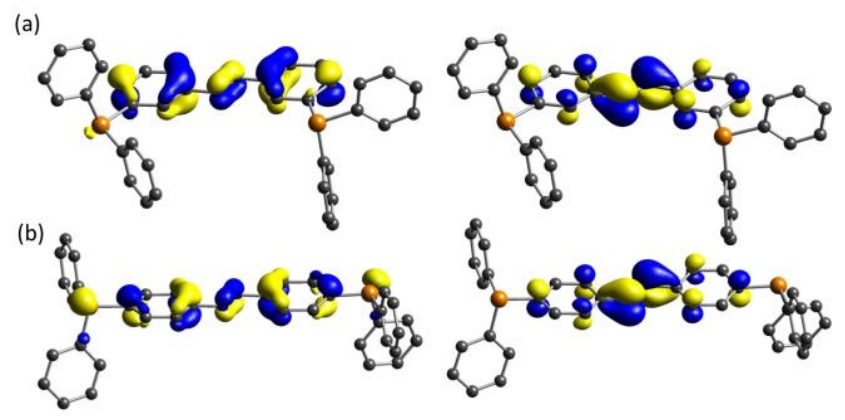

Fig. 8. Dominant natural transition orbitals pairs from holes (left) to particles (right) for electronic transition of (a) $E-3$ at $330 \mathrm{~nm}$ and (b) $E-6$ at $363 \mathrm{~nm}$.
The $\mathrm{S}_{0} \rightarrow \mathrm{S}_{1}$ transitions (showing a dominant $\mathrm{n} \rightarrow \pi^{*}$ character) for both phosphine E-3 and complex E-4 (447 and $449 \mathrm{~nm}$, respectively) are blue-shifted compared to the fluorosubstituted analogues E-1' and E-1 (455 and $456 \mathrm{~nm}$, respectively). The calculated shorter $\mathrm{N}-\mathrm{N}$ bond lengths in $E$ 3/E-4 (1.254 and $1.253 \AA$, respectively) relative to $E-1^{\prime} / E-1$ (1.281 and $1.280 \AA$, respectively), as well as the lower $\Phi$ angle in $E-3 / E-4\left(0.9^{\circ}\right.$ and $1.2^{\circ}$, respectively) as compared to $E-1^{\prime} / E-1$ $\left(3.5^{\circ}\right.$ and $6.7^{\circ}$, respectively, see Table SII and Fig. SI 6,7 and $9,10)$ could be responsible for the observed hypsochromic shift. ${ }^{55}$

The Z-isomers of 3, 4, $\mathbf{6}$ and $\mathbf{7}$ exhibit characteristic absorption bands in the visible region between 434 and $470 \mathrm{~nm}$ (calculated in the range 451-465 $\mathrm{nm}$ ) which are clearly assigned to $n \rightarrow \pi^{*}$ transitions located at the $\mathrm{N}=\mathrm{N}$ moiety of the azobenzene core (Fig. 9 and SI12). The absorption bands in phosphine Z-3 and gold complex Z-4 (434 and $433 \mathrm{~nm}$, respectively) appear at longer wavelengths than in the fluoro-substituted analogues $Z$ 1' (Fig. SI 5) and Z-1 (418 and $422 \mathrm{~nm}$, respectively). A similar hypsochromic shift has been documented previously for the $Z$ isomers of fluorine-substituted azobenzenes vs non-substituted azobenzenes. ${ }^{58}$ It should be related to the increased withdrawal of electron density around the diazene unit.

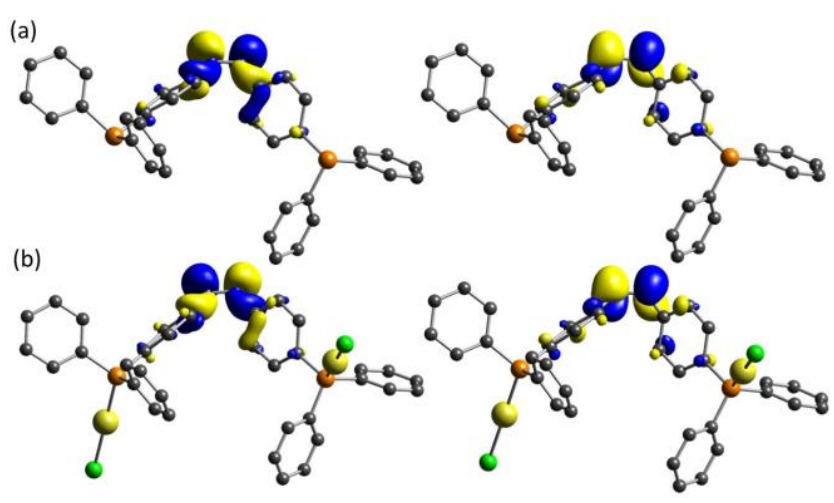

Fig. 9. Dominant natural transition orbitals pairs from holes (left) to particles (right) for electronic transition of (a) Z-6 at 465 and (b) Z-7 at $459 \mathrm{~nm}$.

As expected, the extent of $\mathrm{n} \rightarrow \pi^{*}$ band separation between $E$ and $Z$ isomers is significantly increased in the presence of fluorine atoms, as revealed by $\Delta \lambda\left(n \rightarrow \pi^{*}, E / Z\right)$ values raising from 13 and $16 \mathrm{~nm}$ (for 3 and 4 , respectively) to 37 and $34 \mathrm{~nm}$ (for $\mathbf{1}^{\prime}$ and $\mathbf{1}$, respectively)

\section{Conclusions}

Two novel azobenzene-based diphosphines $\mathbf{3}$ and $\mathbf{6}$ displaying phosphorus functions in meta- and para-positions respectively, have been prepared and their gold(I) complexes have been characterized by X-ray diffraction studies. Absorption spectroscopy and computational methods (DFT and TD-DFT) have been performed to characterize the electronic properties of these compounds. These studies show that the electronic features of azobenzene are almost unchanged when diphenylphosphino functions are introduced on its meta 
positions, while bathochromic shifts of the $\pi \rightarrow \pi^{*}$ absorption bands are induced by phosphorus functions in para-positions. The $E-Z$ photochemistry of the diphosphines and their complexes has been elucidated via UV-vis absorption spectroscopy. The absorption spectra of the meta- derivatives resulted to be similar to the underivated azobenzene and rather insensitive to the complexation. Conversely, the enhanced electronic effect exerted by the phosphines in para- position confers to the azobenzene diphosphine 6 an amino-azobenzene character, which becomes less intense in its $\mathrm{Au}(\mathrm{I})$-complex 7 due to the complexation. All the compounds showed a good $E \rightarrow Z$ photoconversion upon UV irradiation and afforded almost complete recovery of the $E$-isomer upon visible irradiation. The thermal isomerization half-lives resulted to be below 100 minutes for the para-derivatives and higher (270-330 minutes) for the meta-derivatives.

Compounds 3 and 4 have been compared to the parent $o$ fluorinated $m$-azobenzene diphosphine $\mathbf{1}^{\prime}$ and gold complex $\mathbf{1}$, through both experimental and theoretical studies. The results demonstrate the beneficial effect of di-ortho-fluorination, that leads to an increased separation of the $\mathrm{n} \rightarrow \pi^{*}$ bands between $E$ and $Z$-isomers, to a better photoconversion extent, as well as to an increased thermostability of the $Z$-forms.

Overall, the investigations above afford preliminary information on the structural and photophysical properties of azobenzenediphosphines, as a function of their substitution patterns. Such knowledge is an essential prerequisite to develop further applications of azobenzene-diphosphines and their metal complexes in various fields, including photoswitch catalysis.

\section{Experimental section}

\section{General}

All reactions requiring oxygen free conditions were carried out under an argon atmosphere. Toluene and THF were dried before use. Commercially available starting materials were used without further purification. Purification of the products was carried out by flash chromatography using silica gel (35-70 $\mu \mathrm{M})$. ${ }^{1} \mathrm{H},{ }^{31} \mathrm{P}$ and ${ }^{13} \mathrm{C}$ NMR spectra were recorded in $\mathrm{CDCl}_{3}$ on Brucker AV500 or AV300 spectrometers. Chemical shifts are reported in ppm and referenced to residual $\mathrm{CHCl}_{3}$ at $\delta 7.26$ for ${ }^{1} \mathrm{H}$ NMR spectra, and at 77.16 for ${ }^{13} \mathrm{C}$ NMR spectra. Low and high resolution mass spectra [MS(TOF $\mathrm{Cl}+$ )] were recorded on a LCT Waters equipment. Crystals suitable for X-ray analysis were obtained by slow evaporation of a chloroform solution.

\section{General procedure for the synthesis of phosphines $E-3$ and $E-$} 6.

A flame dried Schlenk was charged with the diiodide $\mathbf{2}^{43}$ (or $5^{44}$ ) (0.23 mmol, $100 \mathrm{mg}), \mathrm{Pd}\left(\mathrm{PPh}_{3}\right)_{4}(5 \mathrm{~mol} \%, 13 \mathrm{mg})$ and toluene $(1.2 \mathrm{~mL})$. To the resulting solution, triethylamine $(0.69 \mathrm{mmol}, 96$ $\mu \mathrm{L})$ and diphenylphosphine $(0.51 \mathrm{mmol}, 88 \mu \mathrm{L})$ were added. The mixture was stirred at $100^{\circ} \mathrm{C}$ during $16 \mathrm{~h}$. After cooling to room temperature water was added, the organic layer was separated and the aqueous layer was extracted with dichloromethane. The combined organic layers were dried over $\mathrm{MgSO}_{4}$ and concentrated. The residue was purified by flash chromatography on silica gel (petroleum ether / dichloromethane: 8/2).

E-1,2-bis(3-(diphenylphosphino)phenyl)diazene E-3. $(66 \%$ yield, $84 \mathrm{mg}$, orange solid). ${ }^{1} \mathrm{H} \mathrm{NMR}\left(500 \mathrm{MHz} \mathrm{CDCl}_{3}\right) \delta 7.86$ (d, $J=7.6 \mathrm{~Hz}, 2 \mathrm{H}), 7.81(\mathrm{~d}, J=7.6 \mathrm{~Hz}, 2 \mathrm{H}), 7.46(\mathrm{t}, J=7.5 \mathrm{~Hz}, 2 \mathrm{H})$, 7.42-7.30 (m, 22H); ${ }^{13} \mathrm{C} \mathrm{NMR}\left(75 \mathrm{MHz}, \mathrm{CDCl}_{3}\right) \delta 152.7\left(\mathrm{~d}, J_{C-P}=\right.$ $6.9 \mathrm{~Hz}, \mathrm{C}), 139.1\left(\mathrm{~d}, J_{C-P}=13.2 \mathrm{~Hz}, \mathrm{C}\right), 136.8\left(\mathrm{~d}, J_{C-P}=10.7 \mathrm{~Hz}, \mathrm{C}\right)$, $136.2\left(\mathrm{~d}, J_{C-P}=18.2 \mathrm{~Hz}, \mathrm{CH}\right), 134.0\left(\mathrm{~d}, J_{C-P}=19.7 \mathrm{~Hz}, \mathrm{CH}\right), 133.8$ $\left(\mathrm{d}, J_{C-P}=20.0 \mathrm{~Hz}, \mathrm{CH}\right), 129.4\left(\mathrm{~d}, J_{C-P}=6.9 \mathrm{~Hz}, \mathrm{CH}\right), 129.1(\mathrm{CH})$, $128.8\left(\mathrm{~d}, J_{C-P}=7.0 \mathrm{~Hz}, \mathrm{CH}\right), 122.2(\mathrm{CH}) ;{ }^{31} \mathrm{P} \mathrm{NMR}\left(202 \mathrm{MHz} \mathrm{CDCl}_{3}\right)$ $\delta$-4.9; HRMS (ESI) calcd. for $\mathrm{C}_{36} \mathrm{H}_{29} \mathrm{~N}_{2} \mathrm{P}_{2}[\mathrm{M}+\mathrm{H}]^{+}$: 551.1806; found: 551.1781 .

E-1,2-bis(4-(diphenylphosphino)phenyl)diazene E-6. $(69 \%$ yield, $87 \mathrm{mg}$, orange solid). ${ }^{1} \mathrm{H} \mathrm{NMR}\left(500 \mathrm{MHz} \mathrm{CDCl}_{3}\right) \delta 7.85$ (dd, $\left.J_{H-H}=8.4, J_{H-P}=1.3 \mathrm{~Hz}, 4 \mathrm{H}\right), 7.42\left(\mathrm{dd}, J_{H-H}=8.4 \mathrm{~Hz}, J_{H-P}=6.9 \mathrm{~Hz}\right.$ 4H), $7.39-7.32(\mathrm{~m}, 2 \mathrm{OH}) ;{ }^{13} \mathrm{C} \mathrm{NMR}\left(75 \mathrm{MHz}^{\mathrm{C} C D C l}\right)_{3} \delta 152.8(\mathrm{C})$, $141.7\left(\mathrm{~d}, J_{C-p}=13.5 \mathrm{~Hz}, \mathrm{C}\right), 136.7\left(\mathrm{~d}, J_{C-p}=13.7 \mathrm{~Hz}, \mathrm{C}\right), 134.4(\mathrm{CH})$, $134.1\left(\mathrm{~d}, J_{C-P}=19.7 \mathrm{~Hz}, \mathrm{CH}\right), 129.2(\mathrm{CH}), 128.8\left(\mathrm{~d}, J_{C-P}=7.2 \mathrm{~Hz}\right.$, $\mathrm{CH}), 122.9\left(\mathrm{~d}, J_{C-P}=6.8 \mathrm{~Hz}, \mathrm{CH}\right) ;{ }^{31} \mathrm{P} \mathrm{NMR}\left(202 \mathrm{MHz}, \mathrm{CDCl}_{3}\right) \delta-$ 4.6; HRMS (ESI) calcd. for $\mathrm{C}_{36} \mathrm{H}_{29} \mathrm{~N}_{2} \mathrm{P}_{2}[\mathrm{M}+\mathrm{H}]^{+}$: 551.1806; found: 551.1767.

General procedure for the synthesis of complexes E-4 and E-7. 2,2'-Thiodiethanol $(0.15 \mathrm{mmol}, 15 \mu \mathrm{L})$ was added to $\mathrm{NaAuCl}_{4}\left(\mathrm{H}_{2} \mathrm{O}\right)_{2}(0.076 \mathrm{mmol}, 30 \mathrm{mg})$ in $3 \mathrm{~mL}$ of degassed water at $0^{\circ} \mathrm{C}$. After $5 \mathrm{~min}$, a solution of phosphines E-3 or E-6 $(0.036$ mmol, $20 \mathrm{mg}$ ) in $2 \mathrm{~mL}$ of degassed $\mathrm{CHCl}_{3}$ was added and the mixture was stirred for $40 \mathrm{~min}$ at $0^{\circ} \mathrm{C}$. The reaction mixture was extracted with $\mathrm{CH}_{2} \mathrm{Cl}_{2}$, dried on $\mathrm{MgSO}_{4}$ and concentrated in vacuo. The residue was taken up in a minimal amount of dichloromethane and pentane was added until precipitation. The supernatant was removed and the solid was washed twice with pentane and dried in vacuo.

Complex E-4. (93\% yield, $34 \mathrm{mg}$, orange solid). ${ }^{1} \mathrm{H}$ NMR (500 $\left.\mathrm{MHz}, \mathrm{CDCl}_{3}\right) \delta 8.06-8.00(\mathrm{~m}, 4 \mathrm{H}), 7.66-7.55(\mathrm{~m}, 16 \mathrm{H}), 7.54-7.48$ $(\mathrm{m}, 8 \mathrm{H}) ;{ }^{13} \mathrm{C}$ NMR $\left(75 \mathrm{MHz}, \mathrm{CDCl}_{3}\right) \delta 152.4$ (C), 136.7 (d, $J=13.4$ $\mathrm{Hz}, \mathrm{C}), 134.3$ (d, J=13.9 Hz, CH), 134.2 (d, J = $17.3 \mathrm{~Hz}, \mathrm{C}), 132.4$ (d, $J=2.5 \mathrm{~Hz}, \mathrm{CH}$ ), 130.3 (d, $J=12.2 \mathrm{~Hz}, \mathrm{CH}), 129.7$ (d, $J=10.5$ $\mathrm{Hz}, \mathrm{CH}), 129.6$ (d, J = 12.0 Hz, CH), 129.5 (d, J = $15 \mathrm{~Hz}, \mathrm{CH}), 125.6$ (CH); ${ }^{31} \mathrm{P} N M R\left(202 \mathrm{MHz}, \mathrm{CDCl}_{3}\right.$ ) $\delta$ 33.6; HRMS (ESI) calcd. for $\mathrm{C}_{36} \mathrm{H}_{28} \mathrm{AuN}_{2} \mathrm{P}_{2}\left[\mathrm{M}-\mathrm{AuCl}_{2}\right]^{+}$: 747.1393; found: 747.1424.

Complex E-7. (90\% yield, $33 \mathrm{mg}$, orange solid). ${ }^{1} \mathrm{H}$ NMR (500 $\left.\mathrm{MHz}, \mathrm{CDCl}_{3}\right) \delta 7.99(\mathrm{dd}, J=8.7,2.0 \mathrm{~Hz}, 4 \mathrm{H}), 7.68\left(\mathrm{dd}, J_{\mathrm{H}-\mathrm{H}}=8.6\right.$ $\left.\mathrm{Hz}, J_{H-P}=12.6 \mathrm{~Hz}, 4 \mathrm{H}\right), 7.62-7.54(\mathrm{~m}, 12 \mathrm{H}), 7.55-7.47(\mathrm{~m}, 8 \mathrm{H})$; ${ }^{13} \mathrm{C}$ NMR $\left(75 \mathrm{MHz}, \mathrm{CDCl}_{3}\right) \delta 154.2$ (C), 135.0 (d, $J_{C-P}=14.7 \mathrm{~Hz}$, $\mathrm{CH}), 134.2\left(\mathrm{~d}, J_{C-P}=14.3 \mathrm{~Hz}, \mathrm{CH}\right), 132.3\left(\mathrm{~d}, J_{C-P}=2.3 \mathrm{~Hz}, \mathrm{CH}\right), 129.4$ $\left(\mathrm{d}, J_{C-P}=12.0 \mathrm{~Hz}, \mathrm{CH}\right), 123.5\left(\mathrm{~d}, J_{C-P}=12.8 \mathrm{~Hz}, \mathrm{CH}\right)$; ${ }^{31} \mathrm{P}$ NMR $(202$ $\mathrm{MHz}, \mathrm{CDCl}_{3}$ ) $\delta$ 33.3; HRMS (ESI) calcd. for $\mathrm{C}_{36} \mathrm{H}_{28} \mathrm{AuN}_{2} \mathrm{P}_{2}$ [M$\left.\mathrm{AuCl}_{2}\right]^{+}$: 747.1393; found: 747.1404. 


\section{Absorption spectroscopy.}

Absorption spectra and irradiation experiments were performed in spectroscopic grade acetonitrile (Carlo Erba) previously degassed by argon bubbling. UV-vis absorption spectra were recorded on a Cary 5000 spectrophotometer from Agilent Technologies. Photoisomerization reactions were induced by a $\mathrm{Hg} / \mathrm{Xe}$ Lamp Hamamatsu LC8 Lightningcure, selecting the spectral line by means of an appropriate interference filter (Semrock FF01-315/15-25 + FF01-320/40-25, FF01-335/7-25, FF01-370/10-25, FF01-438/24-25). For thermal isomerization kinetics measurements, a Peltier temperature controller system was employed and the solution was thoroughly stirred over the whole experiment. The kinetic constants of the thermal isomerization processes were extracted by exponential fitting of the absorbance at a single wavelength, according to a first-order kinetic model.

\section{Computational details.}

Ground state geometry optimization by density functional theory (DFT) was performed with the Gaussian16 package at the B3LYP level using LanL2DZ and 6-311G(d,p) (for 3, 4, 6 and 7) or 6-311++G (for $\mathbf{1}$ and $\mathbf{1}^{\prime}$ ) basis sets for gold and all other atoms, respectively. ${ }^{59}$ The absence of imaginary frequencies was checked on all calculated structures to confirm they are true minima. Time dependent density functional theory (TD-DFT) was performed at the CAM-B3LYP level using LanL2DZ and 6$311 \mathrm{G}+(\mathrm{d}, \mathrm{p})$ basis sets for gold and all other atoms, respectively, to compute the 30 lowest singlet states. In all calculations, the effect of solvent (MeCN) was taken into account using C-PCM model. Natural transition orbitals (NTO) analysis was performed on relevant transitions. ${ }^{57}$ Molecular structures, orbitals and computed data were visualized and analysed with Avogadro and Lumo. ${ }^{60,61}$

\section{Acknowledgements}

This work has been supported by the ANR funding agency via the collaborative project "Switch-Phos" (ANR-17-CE07-0032), and the LabEx CHARMMMAT program ANR-11-LABX-0039. Post-doctoral fellowships were provided to T.A. and C.C. by the LabEx and to L.C. by the ANR. The CNRS and the ENS Paris-Saclay are acknowledged for financial support. This work was performed using HPC resources from the "Mésocentre" computing center of CentraleSupélec and École Normale Supérieure Paris-Saclay supported by the CNRS and the Région île-de-France (http://mesocentre.centralesupelec.fr/).

\section{Notes and references}

1 W. Szymański, J. M. Beierle, H. A. V. Kistemaker, W. A. Velema and B. L. Feringa, Chem. Rev., 2013, 113, 6114-6178.

2 V. Garcia-López, D. Liu and J. M. Tour, Chem. Rev., 2020, 120, 79-124.

3 X. Huang and T. Li, J. Mater. Chem. C, 2020, 8, 821-848.

4 D. Dattler, G. Fuks, J. Heiser, E. Moulin, A. Perrot, X. Yao and N. Giuseppone, Chem. Rev., 2020, 120, 310-433.
5 S. Erbas-Cakmak, D. A. Lieigh, C. T. McTernan and A. L. Nussbaumer, Chem. Rev., 2015, 115, 10081-10206.

6 F. Lancia, A. Ryabchun and N. Katsonis, Nature Rev. Chem., 2019, 3, 536-551.

7 M. S. Baroncini, S. and A. Credi, Chem. Rev., 2020, 120, 200268.

8 H. Nie, J. L. Self, A. S. Kuenstler, R. C. Hayward and J. R. de Alaniz, Adv. Optical Mater., 2019, 7, 1900224.

9 C.-L. Sun, C. Wang and R. Boulatov, ChemPhotoChem, 2019, 3 , 268-283.

10 M. Akita, Organometallics, 2011, 30, 35-41.

11 C.-C. Ko and V. W.-W. Yam, Acc. Chem. Res., 2018, 51, 149159.

12 B. Tylkowski, A. Trojanowska, V. Maturano, M. Nowak, L. Marciniak, M. Giamberini, V. Ambrogi and P. Cerruti, Coord. Chem. Rev., 2017, 351, 205-217.

13 S. Samanta, P. Ghosh and S. Goswami, Dalton Trans, 2012, 41, 2213-2226.

14 V. Blanco, D. A. Leigh and V. Marcos, Chem. Soc. Rev., 2015, 44, 5341-5370.

15 R. Dorel and B. L. Feringa, Chem. Commun., 2019, 55, 64776486.

16 S. P. Ihrig, F. Eisenreich and S. Hecht, Chem. Commun., 2019, 55, 4290-4298.

17 Y. Ryu, G. Ahumada and C. W. Bielawski, Chem. Commun., 2019, 55, 4451-4466.

18 D. Sud, R. McDonald and N. R. Branda, Inorg. Chem., 2005, 44, 5960-5962.

19 J. Yin, Y. Lin, X. Cao, G.-A. Yu, H. Tu and S. H. Liu, Dyes Pigm., 2009, 81, 152-155.

20 G. Bianchini, G. Strukul, D. F. Wass and A. Scarso, RSC Adv., 2015, 5, 10795-10798.

21 D. Zhao, T. M. Neubauer and B. L. Feringa, Nat. Commun., 2015, 6:6652 doi: 6610.1038/ncomms7652.

22 R. Costil, S. Crespi, L. Pfeifer and B. L. Feringa, Chem. Eur. J., 2020, 26, 7783-7787.

23 L. Wang, Y. Yu, A. O. Razgoniaev, P. N. Johnson, C. Wang, Y. Tian, R. Boulatov, S. L. Craig and R. A. Widenhoefer, J. Am. Chem. Soc., 2020, 142, 17714-17720.

24 K. Chane-Ching, M. Lequan, R. M. Lequan, C. Runser, M. Barzoukas and A. Fort, J. Mater. Chem., 1995, 5, 649-652.

25 E. Besson, A. Mehdi, V. Matsura, Y. Guari, C. Reyé and R. J. P. Corriu, Chem. Commun., 2005, 1775-1777.

26 M. D. Segarra-Maset, P. W. N. M. van Leeuwen and Z. Freixa, Eur. J. Inorg. Chem., 2010, 2075-2078.

27 M. Yamamura, N. Kano and T. Kawashima, J. Am. Chem. Soc., 2005, 127, 11954-11955.

28 N. Priyadarshani, B. Ginovska, J. T. Bays, J. C. Linehan and W. J. Shaw, Dalton Trans., 2015, 44, 14854-14864.

29 M. Kawamura, R. Kiyotake and K. Kudo, Chirality, 2002, 14, 724-726.

30 C. Poloni, W. Szymański, L. Hou, W. R. Browne and B. L. Feringa, Chem. Eur. J., 2014, 20, 946-951.

31 W. Szymański, B. Wu, C. Poloni, D. B. Janssen and B. L. Feringa, Angew. Chem. Int. Ed., 2013, 52, 2068-2072.

32 Z. Freixa, Catal. Sci. Technol., 2020, 10, 3122-3139.

33 F. Medici, N. Goual, V. Delattre, A. Voituriez and A. Marinetti, ChemCatChem, 2020, 12, 5573-5589.

34 T. Arif, C. Cazorla, N. Bogliotti, N. Saleh, F. Blanchard, V. Gandon, R. Métivier, J. Xie, A. Voituriez and A. Marinetti, Catal. Sci. Technol., 2018, 8, 710-715.

35 S. Sasaki, K. Kato and M. Yoshifuji, Bull. Chem. Soc. Jpn, 2007, 80, 1791-1798.

36 R. Dorel and A. M. Echavarren, Chem. Rev., 2015, 115, 90289072.

37 D. Pflasterer and A. S. K. Hashmi, Chem. Soc. Rev., 2016, 45, 1331-1367. 
38 Z. Lu, G. B. Hammond and B. Xu, Acc. Chem. Res., 2019, 52, $1275-1288$.

39 J. L. Mascareñas, I. Varela and F. López, Acc. Chem. Res., 2019, 52, 465-479.

40 M. J. Alder, K. R. Flower and R. G. Pritchard, J. Organomet. Chem. , 2001, 629, 153-159.

41 J. Liang, J. Yin, Z. Li, C. Zhang, D. Wu and S. H. Liu, Dyes Pigm., 2011, 91, 364-369.

42 B. Li, Y.-H. Wu, H.-M. Wen, L.-X. Shi and Z.-N. Chen, Inorg. Chem., 2012, 51, 1933-1942.

43 A. Antoine John and Q. Lin, J. Org. Chem., 2017, 82, 98739876.

44 W. Liu, L. Zhang, W. Yan, X. Liu, X. Yang, S. Miao, W. Wang, A. Wang and T. Zhang, Chem. Sci., 2016, 7, 5758-5764.

45 H. M. D. Bandara and S. C. Burdette, Chem. Soc. Rev., 2012, 41, 1809-1825.

46 E. Fischer, J. Phys. Chem., 1967, 71, 3704-3706.

47 N. Nishimura, T. Sueyoshi, H. Yamanaka, E. Imai, S. Yamamoto and S. Hasegawa, Bull. Chem. Soc. Jpn, 1976, 49, 1381-1387.

48 The half-life for the parent Z-azobenzene is $4.7 \mathrm{~h}$ at room temperature.

49 D. Bléger, J. Schwarz, A. M. Brouwer and S. Hecht, J. Am. Chem. Soc., 2012, 134, 20597-20600.

50 C. Knie, M. Utecht, F. Zhao, H. Kulla, S. Kovalenko, A. M Brouwer, P. Saalfrank, S. Hecht and D. Bléger, Chem. Eur. J., 2014, 20, 16492-16501.

51 X.-M. Liu, X.-Y. Jin, Z.-X. Zhang, J. Wang and F.-Q. Bai, RSC Adv., 2018, 8, 11580-11588.

52 J. Calbo, A. R. Thawani, R. S. L. Gibson, A. J. P. White and M. J. Fuchter, Beilstein J. Org. Chem., 2019, 15, 2753-2764.

53 The parent $Z-2,2^{\prime}, 6,6^{\prime}$-tetrafluoroazobenzene showed a halflife $\mathrm{t} 1 / 2=2187.6 \mathrm{~h}$ at room temperature in $\mathrm{MeCN}$.

54 J. Harada and K. Ogawa, J. Am. Chem. Soc., 2004, 126, 35393544.

55 D. B. Konrad, G. Savasci, L. Allmendinger, D. Trauner, C. Ochsenfeld and A. M. Ali, J. Am. Chem. Soc., 2020, 142, 65386547.

56 D. Jacquemin, J. Preat, E. A. Perpète, D. P. Vercauteren, J.-M André, I. Ciofini and C. Adamo, Int. J. Quantum Chem., 2011, 111, 4224-4240.

57 R. L. Martin, J. Chem. Phys., 2003, 118, 4775-4777.

58 A. Goulet-Hanssens, M. Utecht, M. Mutruc, E. Titov, J. Schwarz, L. Grubert, D. Bléger, P. Saalfrank and S. Hecht, J. Am. Chem. Soc., 2017, 139, 335-341.

59 Gaussian 16, Revision B.01, M. J. Frisch, G. W. Trucks, H. B. Schlegel, G. E. Scuseria, M. A. Robb, J. R. Cheeseman, G. Scalmani, V. Barone, G. A. Petersson, H. Nakatsuji, X. Li, M. Caricato, A. V. Marenich, J. Bloino, B. G. Janesko, R. Gomperts, B. Mennucci, H. P. Hratchian, J. V. Ortiz, A. F. Izmaylov, J. L. Sonnenberg, Williams, F. Ding, F. Lipparini, F. Egidi, J. Goings, B. Peng, A. Petrone, T. Henderson, D. Ranasinghe, V. G. Zakrzewski, J. Gao, N. Rega, G. Zheng, W. Liang, M. Hada, M. Ehara, K. Toyota, R. Fukuda, J. Hasegawa, M. Ishida, T. Nakajima, Y. Honda, O. Kitao, H. Nakai, T. Vreven, K. Throssell, J. A. Montgomery Jr., J. E. Peralta, F. Ogliaro, M. J. Bearpark, J. J. Heyd, E. N. Brothers, K. N. Kudin, V. N. Staroverov, T. A. Keith, R. Kobayashi, J. Normand, K. Raghavachari, A. P. Rendell, J. C. Burant, S. S. Iyengar, J. Tomasi, M. Cossi, J. M. Millam, M. Klene, C. Adamo, R. Cammi, J. W. Ochterski, R. L. Martin, K. Morokuma, O. Farkas, J. B. Foresman and D. J. Fox Gaussian, Inc., Wallingford, CT, 2016

60 M. D. Hanwell, D. E. Curtis, D. C. Lonie, T. Vandermeersch, E. Zurek and G. R. Hutchinson, J. Cheminformatics, 2012, 4, 17.

61 http://www.kieber-emmons.com/Lumo/ 